\title{
PHENOLOGICAL CHARACTERISTICS OF GENOTYPES FROM CATTLEY GUAVA AND GUAVA TREES SUBMITTED TO FRUCTIFICATION PRUNING ${ }^{1}$
}

\author{
CINTIA APARECIDA BREMENKAMP², CLÁUDIA SALES MARINHO \\ GRAZIELLA SIQUEIRA CAMPOS ${ }^{4}$
}

\begin{abstract}
Psidium cattleianum Sabine is a species from the Myrtaceae family that serves as an option for the native fruits cultivation, besides being considered a source of resistance to the Meloidogyne enterolobii nematode. Although cattley guava trees from this species produce flower buds in young branches, there are no reports of response to fructification pruning or phenological synchronism with the guava tree. The objective of this paper was the comparative evaluation of the genotype response of strawberry guava trees and guava cultivars to fructification pruning, thus, describing the phenology of both species under the same cultivation conditions. The experiment was conducted under an entirely randomized outline, in $7 \times 2$ factorial scheme, being evaluated seven genotypes (three from strawberry guava and four from guava trees), and with pruning performed in two seasons (May 2012 and March 2013), with three repetitions. Fructification pruning was executed by a lopping on all mature branches, from the last growth flow in the woody branch region. Were evaluated budding characteristics and fruit harvesting, as well as number of days from pruning to the observation of the phenological event. Cattley guava tree pruning stimulated fructification of all three genotypes after pruning done on May and two genotypes after the March's pruning. There has been a sync between the guava cultivars' flowering and both strawberry guava trees genotypes, when those were pruned on May.
\end{abstract}

Index Terms - Psidium cattleianum; Psidium guajava; 'Paluma', 'Pedro Sato', 'Cortibel 4' and 'Cortibel 6'

\section{CARACTERÍSTICAS FENOLÓGICAS DE GENÓTIPOS DE ARAÇAZEIROS E GOIABEIRAS SUBMETIDOS À PODA DE FRUTIFICAÇÃO}

RESUMO-Psidium cattleianum Sabine é uma espécie da família Myrtaceae que serve como opção para o cultivo de frutas nativas, além de ser considerada fonte de resistência ao nematoide Meloidogyne enterolobii. Embora araçazeiros dessa espécie produzam botões florais em brotações jovens, não há relatos de sua resposta a podas de frutificações ou de sincronismo de sua fenologia com a da goiabeira. O objetivo deste trabalho foi a avaliação comparativa da resposta de genótipos de araçazeiros e cultivares de goiabeiras à poda de frutificação, descrevendo assim a fenologia das duas espécies sob as mesmas condições de cultivo. $\mathrm{O}$ experimento foi conduzido sob delineamento inteiramente casualizado, em esquema fatorial $7 \mathrm{x} 2$, sendo avaliados sete genótipos (três de araçazeiro e quatro de goiabeira), e podas efetuadas em duas épocas (maio de 2012 e março de 2013), com três repetições. A poda de frutificação foi executada por um desponte em todos os ramos maduros, do último fluxo de crescimento, na região lenhosa do ramo. Em oito ramos por planta, foram avaliadas as características de brotações e do pegamento de frutos, assim como o número de dias transcorridos da poda à observação do evento fenológico. A poda do araçazeiro estimulou a frutificação de todos os três genótipos após a poda efetuada em maio e de dois genótipos após a poda efetuada em março. Houve sincronia entre o florescimento das cultivares de goiabeira e de dois dos genótipos de araçazeiros, quando estes foram podados em maio.

Termos para Indexação - Psidium cattleianum; Psidium guajava; 'Paluma', 'Pedro Sato', 'Cortibel 4' e 'Cortibel 6'.

\footnotetext{
1(Paper 141-15). Received May 28, 2015. Accepted February 24, 2016.

${ }^{2}$ Agronomist, Doctorate in Plant Production, State University of Norte Fluminense Darcy Ribeiro. E-mail: cintia.bremenkamp@ gmail.com

${ }^{3}$ Agronomist, Associate Professor, State University of Norte Fluminense Darcy Ribeiro, CCTA / LFIT - Av. Alberto Lamego, 2000, Campos dos Goytacazes-RJ. E-mail: marinho@uenf.br

${ }^{4}$ Agronomist, Master of Science in Plant Production, State University of Norte Fluminense Darcy Ribeiro. E-mail: grasicam@gmail. com
} 


\section{INTRODUCTION}

Meloidogyne enterolobii is a phytonematode that has been causing losses to the guava cultivation in many States of Brazil and in other countries. Resistance to $M$. enterolobii was not reported in Psidium guajava, but was reported in cases of $P$. cattleianum (Sabine) and P. friedrichsthalianum (FREITAS et al., 2014). In this context, some cases of $P$. cattleianum resistant to the nematode were evaluated as rootstocks for guavas by Robaina et al. (2015), that found incompatibility symptoms between both species, like the hypertrophy of the graft's region, low vigor and death of the plants about a year after planting. Therefore, interspecific hybridizations are strategic for the genotype development of guava tree scions or grafts resistant to $M$. enterolobii and knowledge of the phenological characteristics of cattley guava trees is necessary.

Although this species of cattley guava produces flower buds in young buddings, there are no reports of response to fructification pruning or phenological synchronism with the guava tree. Bauer et al. (2014) evaluated the phenology of the $P$. cattleianum individuals inside an afforestation in Rio Grande do Sul (Brazil) and found that, under those conditions, cattley guava emitted flower buds once a year, starting on October, at spring.

Guava produces flowers at young branches and pruning can be performed during many times of the year, aiming to induce flowering and fructification, provided that there are water and adequate temperatures. In Mexico, guava cultivars successively submitted to fructification pruning blossomed during winter, spring and summer, with minimal temperatures between 12 and 26 ${ }^{\circ} \mathrm{C}$. It was also observed up to a 30 -day interval between opening these cultivars flowers, attributed to genotypic differences, provided that cultivating and environment conditions are the same (PÉREZBARRAZ et al., 2015).

Phenology knowledge is fundamental to evaluate cultivation viability and establishing appropriate handling and, in case of genetic enhancement, might even be able to schedule the crossing seasons. In this sense cattley guava and guava flowering synchronization may, as hypothesis, be reached through fructification pruning in order to facilitate the accomplishment of artificial hybridizations. However, there is the necessity to know if, for the cattley guava, there is stimulus to fructification through pruning.

The objective of this paper was to evaluate phenological characteristics of cattley guava $(P$. cattleianum) and guava genotypes submitted to fructification pruning under the same cultivation conditions, in the north of Rio de Janeiro state, Brazil.

\section{MATERIALS AND METHODS}

The experiment was conducted under an entirely randomized outline, in a $7 \times 2$ factorial scheme. Factors consisted in seven genotypes (three from strawberry guava of the Psidium catlleyanum and four from guava cultivars) and two pruning seasons (May 2012 and March 2013), with three repetitions and experimental parcel constituted by eight branches per plant.

Used cattley guava trees genotypes were from three different places: sandbank (AR), farmer's selection (AS) and urban tree (AU). The three cattley guava groups produce yellow (AR and AS) or purple (AU) fruits.

Utilized guava genotypes were Paluma, Pedro Sato, Cortibel 4 and Cortibel 6 cultivars.

The experiment was conducted at Campos dos Goytacazes - RJ, Brazil. According to Köppen's classification it is a humid tropical climate (Aw), with rainy summer and dry winter, temperature on the coldest month was above $18^{\circ} \mathrm{C}$, average annual temperature was around $24{ }^{\circ} \mathrm{C}$ and annual rainfall was around $1023 \mathrm{~mm}$, focused on October and January.

The experimental area soil is classified as Yellow Latosol, dystrophic, sandy texture. Cattley guava seedlings were produced through seeds obtained from collected fruits in the sandbank region of São João da Barra - RJ and, also, fruits collected from urban trees at the Campos dos Goytacazes city - RJ. Guava seedlings were produced through herbaceous cuttings, from commercial cultivations.

Lopping of all previous growth flow was performed in a way that the cut was done on the woody region of the branch, right beneath the braches' transition area from the semi-woody to the woody stage. During the pruning performance, all fruits and flowers on the plant were eliminated. Pruning was performed on May $23^{\text {nd }}, 2012$ and March $22^{\text {nd }}, 2013$.

After pruning, eight branches per plant were selected (two per quadrant) for the evaluation of the following botanical characteristics, until the third pair of leaves of the emitted budding: number of bud (NBM); number of emitted buds (NEB); number of established branches (NSB); percentage of established branches [(NSB/NBE) x 100]; number of flower buds emitted (NFB); number of fruits (NFR). Obtained data were transformed in 
$\sqrt{(\mathrm{x}+0,5)}$ and submitted to variance analysis. In case of significance, averages of the treatments were compared by the Tukey test at $5 \%$ probability.

\section{RESULTS AND DISCUSSION}

It was not verified any effects of the treatments from the pruning and the beginning of tumescence of buds, that was verified at 21 days for all genotypes. Average time from the pruning and tumescence of buds was different among genotypes, regardless the pruning. tumescence of bud occurred before for the 'Paluma' and 'Pedro Sato' guava trees (Table 1).

In general, flower buds' tumescence occurred before on the guava cultivars and the AS and AU cattley guava (Table 1). In average, the AR genotype took longer to emit flower buds on both studied periods. As result of the May 2012 pruning, even with the AS genotype emitting flowers before, the harvesting of their fruits occurred along with the $A R$ genotype. For the AU genotype, in its turn, harvesting was verified during the same season of the guava. For the 2013 season, flower buds' emission for the AU genotype was not verified and this tendency could not be confirmed (Table 2).

On the May 2012 pruning, full flowering occurred at the same period for the guava genotypes and the AR and AU cattley guava genotypes, next to the 84 days after pruning. The AS genotype presented flowering at 91 days after pruning. On the March 2013 pruning, full flowering was early and the AS flourished early, next to 70 days after pruning and other genotypes 77 days after pruning. Bauer et al. (2014) did not observe influence of climatic factors (such as radiation, precipitation and temperature) over the Psidium cattleianum flowering, however a relation between length of the day and temperature with the presence of fruits was observed.

At Mexico, phenology of guava cultivars of cream and pink pulp (among them the Paluma cultivars) was reported by Pérez-Barraza et al. (2015). On the research paper, fructification pruning was performed after each harvest and consisted on lopping 2/3 of the plants' branches. On the first evaluation year there was difference between the different cultivars regarding seasons and flourishing frequency. On the third year, after continuous pruning, all evaluated cultivars flourished during winter, spring and summer, with minimal temperatures between 12 and $26^{\circ} \mathrm{C}$. Also observed that there was a 30-day interval between the flower opening of these cultivars.

The same authors observed that, when submitted to continuous pruning, always after fruit harvest, there was difference between different cultivars on the first evaluation year.

In work with guava pruning at Campos dos Goytacazes - RJ, Oliveira (2013) observed the beginning of flowering between 45 and 62 days after pruning for different guava genotypes, values close to the ones found on this experiment, except for AS genotypes.

For the second pruning season, AU genotype plants did not present flower buds emission neither fruits, consequently. However, it was observed that other plants of the same genotype planted at the same area and with the same cultivation presented flowering during the period that should be emitted flower buds after pruning, suggesting that the March pruning might have inhibited the plants' flowering.

According to Danner et al. (2010) heterogeneity of the reproductive cycle of plants from the same species it is indicative of genetic variability, usually found among sexually propagated plants. This makes possible to plan crossing in genetic enhancement programs and harvest stagger in commercial cultivations. Yet, according to the same authors, when the goal is homogeneity of harvest and maturation in commercial cultivations, asexual propagation techniques must be developed to each species.

The pruning season significantly influenced response of the genotypes at the number of bud, of flower buds and number of fruits characteristics (Table 3).

The number of emitted buds was influenced by the pruning season and was bigger for the AS and AR cattley guava, after the May 2012 pruning. After the March 2013 pruning, there was a tendency for the cattley guava trees to be even with the guava regarding the number of buds sprouted, although the AU cattley guava was the only with larger number of buds sprouted, when compared to the guava.

The AS genotype presented larger number of flower buds and fruits than other genotypes, being the only one to present good results for the flower buds and fruits emission after the March pruning.

The small number of flower observed for the March pruning, to most evaluated genotypes, may be explained through the small budding number, what suggests that the plants tend to a vegetable growth in over the production, once the excessive vegetable growth reduces fruit production.

In study of the flowering induction of $P$. cattleianum with nitrogen fertilizing, Norman and Habib (2001) observed that the phenological stage of the plant had strong influence over the fertilizing response, with a more intensive flowering and less 
variable when the fertilization was applied after a rest period of three months than right after the harvest, suggesting that availability of carbohydrates inside the plant was involved at the response.

For the conditions of this experiment was observed that the harvest of $P$. cattleianum fruits occurred between October and February, and the March pruning was right after this harvest, what might have influenced the pruning response for most of the evaluated genotypes, both for guavas and cattley guava.

May 2012 pruning provided better results for the number of tumescent buds and established buddings than the March 2013 (Table 4). Among the genotypes was observed that, in average, Cortibel 4 and Cortibel 6 guavas had the least number of buds when compared to the AU cattley guava, that, even not differing from the other genotypes concerning this characteristic, considering the average of two pruning seasons. For the established branches numbers difference between genotypes was not verified. Thus, the greater number of buds did not result in a larger number of established branches, demonstrating a clear competition between buds for their establishment, which was also observed by Serrano et al. (2008) for the 'Paluma' guava pruning at the North of Espírito Santo.

The number of established branches did not statistically differ among genotypes, showing better average results for the May 2012 pruning. Serrano et al. (2008) also observed pruning season influence over the number of emitted buds and established branches studying the 'Paluma' guava in the North region of Espírito Santo.

TABLE 1- Days from the fructification pruning, in two seasons, and the buds number (NBM) and the cattley guava (Psidium cattleianum) sprouted buds (NEB) and guava cultivars. Campos dos Goytacazes, RJ, 2015.

\begin{tabular}{|c|c|c|c|c|c|}
\hline \multirow{2}{*}{ Genotype } & \multicolumn{2}{|c|}{ - } & \multicolumn{3}{|c|}{--1 } \\
\hline & May/12 & $\operatorname{March} / 13$ & May/12 & March/13 & Average \\
\hline $\mathrm{AS}^{*}$ & 21 & 21 & 28 & 28 & $28 \mathrm{a}$ \\
\hline $\mathrm{AR}^{*}$ & 21 & 21 & 30 & 30 & $30 \mathrm{a}$ \\
\hline $\mathrm{AU}^{*}$ & 21 & 21 & 28 & 28 & $28 \mathrm{a}$ \\
\hline Cortibel4 & 21 & 21 & 28 & 28 & $28 \mathrm{a}$ \\
\hline Cortibel6 & 21 & 21 & 26 & 26 & $26 \mathrm{ab}$ \\
\hline Paluma & 21 & 21 & 23 & 21 & $23 \mathrm{~b}$ \\
\hline Pedro Sato & 21 & 21 & 23 & 23 & $23 b$ \\
\hline CV (\%) & \multicolumn{2}{|c|}{ - } & \multicolumn{3}{|c|}{13,6} \\
\hline
\end{tabular}

Averages followed by the same lowercase letter on the column do not differ among themselves through the Tukey test at $5 \%$ probability ns - non-significant at $5 \%$ probability through the $\mathrm{F}$ test.

*AR, AS and AU show the origin of the strawberry guava, being from sandbank or farmer's selection, both from São João da Barra RJ and urban trees from Campos dos Goytacazes - RJ. 
TABLE 2 -Days from the fructification pruning, in two seasons, number of flower from sprouted buds (NFB) and the cattley guava (Psidium cattleianum) number of fruits (NFR) and guava cultivars. Campos dos Goytacazes, RJ, 2015.

\begin{tabular}{cccccc}
\hline \multirow{2}{*}{ Genotype } & May/12 & March/13 & Average & May/12 & March/13 \\
\hline AS $^{*}$ & 32 & 35 & $34 \mathrm{~b}$ & $105 \mathrm{a} \mathrm{A}$ & $98 \mathrm{a} \mathrm{A}$ \\
$\mathrm{AR}^{*}$ & 63 & 56 & $60 \mathrm{a}$ & $98 \mathrm{ab} \mathrm{A}$ & $85 \mathrm{~b} \mathrm{~B}$ \\
$\mathrm{AU}^{*}$ & 35 & - & - & $81 \mathrm{c}$ & - \\
Cortibel4 & 42 & 42 & $42 \mathrm{~b}$ & $86 \mathrm{bc} \mathrm{A}$ & $89 \mathrm{ab} \mathrm{A}$ \\
Cortibel6 & 42 & 44 & $43 \mathrm{~b}$ & $84 \mathrm{c} \mathrm{A}$ & $84 \mathrm{~b} \mathrm{~A}$ \\
Paluma & 39 & 39 & $39 \mathrm{~b}$ & $88 \mathrm{bc} \mathrm{A}$ & $86 \mathrm{ab} \mathrm{A}$ \\
Pedro Sato & 37 & 37 & $37 \mathrm{~b}$ & $84 \mathrm{c} \mathrm{A}$ & $84 \mathrm{~b} \mathrm{~A}$ \\
\hline Average & $41 \mathrm{~A}$ & $42 \mathrm{~A}$ & - & - & - \\
\hline CV (\%) & \multicolumn{7}{c}{ 36,2 } & & & & 29,3 \\
\hline
\end{tabular}

Averages followed by the same lowercase letter on the column or uppercase letter on the line do not differ among themselves through the Tukey test at $5 \%$ probability.

*AR, AS and AU show the origin of the strawberry guava, being from sandbank or farmer's selection, both from São João da Barra RJ and urban trees from Campos dos Goytacazes - RJ.

TABLE 3- Number of bud (NBM), flower buds sprouted (NFB) and fruits (NFR) in branchs of cattley guava (Psidium cattleianum) and guava cultivars submitted to fructification pruning in two seasons, Campos dos Goytacazes, RJ, 2015.

\begin{tabular}{|c|c|c|c|c|c|c|}
\hline \multirow{2}{*}{ Genotype } & \multicolumn{2}{|c|}{-----------NBM----------- } & \multicolumn{2}{|c|}{ - } & \multicolumn{2}{|c|}{---------------NFR------------ } \\
\hline & May/12 & March/13 & May/12 & $\mathrm{March} / 13$ & May/12 & $\operatorname{March} / 13$ \\
\hline $\mathrm{AS}^{*}$ & 4,8 a $\mathrm{A}$ & $2,1 \mathrm{ab} B$ & 24,3 a $\mathrm{A}$ & 11,4 a B & 17,4 a A & 8,7 a $\mathrm{B}$ \\
\hline $\mathrm{AR}^{*}$ & 3,9 a $\mathrm{A}$ & $2,3 \mathrm{ab} B$ & $2,0 \mathrm{~d} A$ & $0,5 \mathrm{~b} \mathrm{~A}$ & 0,6 e $\mathrm{A}$ & $0,4 \mathrm{~b} \mathrm{~A}$ \\
\hline $\mathrm{AU}^{*}$ & $1,4 \mathrm{~b} \mathrm{~B}$ & 4,2 a $\mathrm{A}$ & $3,8 \mathrm{~cd} \mathrm{~A}$ & $0,0 \mathrm{~b} \mathrm{~B}$ & 1,7 de $\mathrm{A}$ & $0,0 \mathrm{~b} \mathrm{~B}$ \\
\hline Cortibel4 & $1,5 \mathrm{~b} \mathrm{~A}$ & $1,4 \mathrm{~b} \mathrm{~A}$ & $9,3 \mathrm{bc} \mathrm{A}$ & $2,6 \mathrm{~b} \mathrm{~B}$ & $6,5 \mathrm{bc} \mathrm{A}$ & $2,0 \mathrm{~b} \mathrm{~B}$ \\
\hline Cortibel6 & $1,0 \mathrm{~b} \mathrm{~A}$ & $1,4 \mathrm{~b} \mathrm{~A}$ & $7,1 \mathrm{c} \mathrm{A}$ & $1,3 \mathrm{~b} \mathrm{~B}$ & $4,5 \mathrm{~cd} A$ & $0,8 \mathrm{~b} \mathrm{~B}$ \\
\hline Paluma & $1,3 \mathrm{~b} \mathrm{~A}$ & $1,5 \mathrm{~b} \mathrm{~A}$ & $15,4 \mathrm{~b}$ A & $1,1 \mathrm{~b} \mathrm{~B}$ & $12,5 \mathrm{ab} A$ & 0,4 b B \\
\hline Pedro Sato & $1,2 \mathrm{~b} \mathrm{~A}$ & $1,3 \mathrm{~b} \mathrm{~A}$ & 9,3 bc A & $1,6 \mathrm{~b} \mathrm{~B}$ & 7,4 bc $\mathrm{A}$ & $0,7 \mathrm{~b}$ B \\
\hline $\mathrm{CV}(\%)$ & \multicolumn{2}{|c|}{8,9} & \multicolumn{2}{|c|}{28,3} & \multicolumn{2}{|c|}{26,5} \\
\hline
\end{tabular}

Averages followed by the same lowercase letter on the column or uppercase letter on the line do not differ among themselves through the Tukey test at $5 \%$ probability.

*AR, AS and AU show the origin of the strawberry guava, being from sandbank or farmer's selection, both from São João da Barra RJ and urban trees from Campos dos Goytacazes - RJ. 
TABLE 4- Number of sprouted buds (NEB) and number of established branches (NSB), in branchs of cattley guava (Psidium cattleianum) and guava cultivars submitted to fructification pruning in two seasons, Campos dos Goytacazes, RJ, 2015.

\begin{tabular}{cccccc}
\hline \multirow{2}{*}{ Genotype } & May/12 & March/13 & Average & May/12 & March/13 ${ }^{\text {ns }}$ \\
\hline $\mathrm{AS}^{*}$ & 4,3 & 2,5 & $3,4 \mathrm{ab}$ & 2,3 & 1,5 \\
$\mathrm{AR}^{*}$ & 3,5 & 1,7 & $2,6 \mathrm{ab}$ & 3,0 & 1,4 \\
$\mathrm{AU}^{*}$ & 3,6 & 4,2 & $3,8 \mathrm{a}$ & 3,1 & 2,3 \\
Cortibel4 & 2,8 & 1,5 & $2,1 \mathrm{~b}$ & 2,5 & 1,4 \\
Cortibel6 & 2,4 & 1,9 & $2,1 \mathrm{~b}$ & 2,2 & 1,8 \\
Paluma & 3,6 & 2,0 & $2,8 \mathrm{ab}$ & 3,2 & 1,1 \\
Pedro Sato & 3,3 & 2,1 & $2,7 \mathrm{ab}$ & 3,1 & 1,8 \\
\hline Average & $3,4 \mathrm{~A}$ & $2,3 \mathrm{~B}$ & - & $2,8 \mathrm{~A}$ & \\
\hline CV (\%) & & 6,9 & & & 6,1 \\
\hline
\end{tabular}

Averages followed by the same lowercase letter on the column or uppercase letter on the line do not differ among themselves through the Tukey test at $5 \%$ probability. . ${ }^{\mathrm{ns}}$ - non-significant at $5 \%$ probability through the $\mathrm{F}$ test to Genotype.

*AR, AS and AU show the origin of the strawberry guava, being from sandbank or farmer's selection, both from São João da Barra RJ and urban trees from Campos dos Goytacazes - RJ.

\section{CONCLUSION}

The cattley guava pruning stimulated fructification of all three evaluated genotypes after the May pruning and two genotypes for the March pruning. There was synchrony between the guava cultivars and two cattley guava genotypes pruned in May.

\section{ACKNOWLEDGEMENTS}

To FAPERJ and CAPES for the PHD scholarships of the first and third authors, respectively.

\section{REFERENCES}

BAUER, D., MÜLler, A., GOETZ, M.N.B., SCHMITT, J.L. Fenologia de Ocotea pulchella, Myrcia brasiliensis e Psidium cattleianum, em floresta semidecídua do Sul do Brasil. Floresta, Curitiba, v.44, n.4, p.657-668, 2014.

DANNER, M.A., CITADIN, I., SASSO, S.A.Z., SACHET, M.R., AMBRÓSIO, R. Fenologia da floração e frutificação de mirtáceas nativas da floresta com araucária. Revista Brasileira de Fruticultura, Jaboticabal, v.32, n.1, p.291-295, 2010.
FREITAS, V.M., CORREA, V.R., MOTTA, F.C., SOUSA, M.G., GOMES, A.C.M.M., CARNEIRO, M.D.G., SILVA, D.B., MATTOS, J. K., NICOLE, M., CARNEIRO, R.M.D.G. Resistant accessions of wild Psidium spp. to Meloidogyne enterolobii and histological characterization of resistance. Plant Pathology, London, v.63, p.738-746, 2014.

NORMAND, F., HABIB, R. Nitrogen fertilization induces floriferous flush in strawberry guava (Psidium cattleianum). Agronomie, Les Ulis, v.21, p.735-742, 2001.

OLIVEIRA, N.N.S. Fenologia de genótipos selecionados de goiabeira (Psidium guajava $\mathrm{L}$.) e caracterização molecular de acessos de Psidium spp. via marcadores ISSR. 2013. 55f. Dissertação (Mestrado em Genética e Melhoramento de Plantas) - Universidade Estadual do Norte Fluminense, Campos dos Goytacazes, 2013.

PÉREZ-BARRAZA, M.H., OSUNA-GARCÍA, J.A., PADILLA-RAMÍREZ, J.S., SÁNCHEZ-LUCIO, R., NOLASCO-GONZÁLEZ, Y., GONZÁLEZGAONA, E. Fenología, productividad y calidad de fruto de guayaba pulpa crema y rosa en clima tropical en México. Interciencia, Caracas, v. 40, n.3, p. 198-203, 2015. 
ROBAINA, R.R., CAMPOS, G.S., MARINHO, C.S., $\quad$ SERRANO, L.A.L.; MARTINS, M.V.V.; LIMA, SOUZA, R.M., BREMENKAMP, C.A. Grafting I.M.; MARINHO, C.S.; TARDIN, F.D. Épocas e guava on cattley guava resistant to Meloidogyne intensidades de poda de frutificação na goiabeira enterolobii. Ciência Rural, Santa Maria, v.45, n.9, 'Paluma', em Pinheiros - ES. Revista Brasileira de p.1579-1584, 2015.

Fruticultura, Jaboticabal, v.30, n.4, p.994-1000, 2008. 